NEVENA DAKOVIĆ

Department of Theory and History

University of Arts, Belgrade

\title{
Memory images: Holocaust memory in Balkan cinema(s)
}

\begin{abstract}
Daković Nevena, Memory images: Holocaust memory in Balkan cinema(s). „Images” vol. XXIII, no. 32. Poznań 2018. Adam Mickiewicz University Press. Pp. 25-27. ISSN 1731-450X. DOI 10.14746/i.2018.32.03.

The aim of this paper is to analyse the shift of the representational and narrative paradigms of Holocaust memory in the Balkan films that belong to two genres - of melodrama and historical fiction. The hybrid format positons the Holocaust (hi)stories - already caught between forgetting and remembrance - on the unstable ground between trauma and nostalgia; between history and memory; or facts and fiction. The "regained visibility of the Holocaust grant us access" to Balkan past and present and oblige us to investigate the convergence of the history and the memory into Holocaust master narrative of the Holocaust.

"Bringing the dark past to light" in cinema has manifold effect. First, the Balkan wave of Holocaust films, with its mixed generic performances, offers new answers to the traditional issues of, both, the ethics of memory and the ethics of representation. Second, the analysis of five films reveals that the trauma from the past - resisting the closure - has the potential to powerfully resonate in the present day political crises. Re-dressing the trauma of the past, the films present the future violence while fulfilling "the Holocaust dictum 'never forget". Eventually, new representational paradigm gives consistency to the Balkan (hi)stories of the past and coherence to the identity in the present.
\end{abstract}

KEYWORDs: Balkan cinema(s), Holocaust, memory, trauma, history

"Certain matters require the generosity of forgetfulness, and others demand the honesty of remembrance" [1]

The notion of the Balkans persists in contradictions and secrets[2]; it resists even the clear geographical and geopolitical determination or genesis of the name,[3] and consequently determines the ambivalence and elusiveness of all other terms related to it. The Balkan cinema, thus, exists in two basic meanings. It refers to the set of cinemas from the region differentiated along state and ethnic borders. But it also implies a monolithic group of films produced in the region - with a multi-ethnic or multicultural identity, or the supra-identity of the post national era - which itself is not clearly delineated. The duality "of singular and plural" is solved by the term "Balkan cinema(s)". This suggests that conclusions about the films coming from a range of dis-

[1] D. Barenboim, E. Said, Parallels and Paradoxes: Explorations in Music and Society, New York 2004, p. 169. [2] M. Todorova, Imagining the Balkans, New York 1997; L. Wolff, Inventing Eastern Europe: The Map of Civilization on the Mind of the Enlightenment, Stanford 1994; D. Iordanova, Cinema of Flames: Balkan Film, Culture, and the Media, London 2001; N. Da-
Images vol. XXIII/no. 32

Poznań 2018

ISSN 1731-45OX 
tinctive Balkan countries - from Serbia to Turkey and from Bosnia to Bulgaria - is also valid for the Balkans understood as a Deleuzian "smooth space" with no demarcation lines drawn within it. The shared topics of the cinematic narratives assert the coherence of the analysis of the contemporary Balkan cinema(s);[4] a thematic fil rouge allows the comparative research of films from different states while preserving the concept of the Balkans ' rich heritage of "unity in diversity".

The theme that defines the case studies in this paper is the Holocaust. The aim of this paper is to analyse shifts in representational and narrative paradigms of Holocaust memory in Balkan cinema(s), i.e. in films belonging to two genres - melodrama and historical fiction - and vacillating between nostalgia and trauma. The "regained visibility of the Holocaust grants us access" [5] to the Balkan past and allow us to investigate the complex interrelations between Holocaust memory and cinema. Furthermore, the paper maps out the ways in which new cinematic narratives (re)define the notions of the shared history, memory, past and identity of the Balkans. Balkan Holocaust films, with their mixed generic performances, develop the debate about the ethics of memory and the ethics of representation of the Holocaust. Cinematic stories reveal the Holocaust memory in the Balkans to be equally local and global; national/regional and cosmopolitan; territorialized rather than deterritorialized; more mediatized than non-mediatized. The memory and history converge in the cinematic master Holocaust narrative, that burdened by "ethic significance and responsibility" [6] and reaching "beyond the "unpresentable", nonetheless rewrite the Balkan past as the one that affects and defines its present and identity and is seen as working toward both concepts - national and transnational/regional.

\section{Cinematic memories of the Holocaust}

For a long time after World War II, the Holocaust was largely marginalized both in societies and cinemas - treated carefully in accordance with the political context - lingering on as an unsettled, dissonant past wrapped up in a shameful silence. Sustained by the "memory boom" in the 1980 os, it began to be intensively revived and retold. The proliferation of various texts in diverse media guises not only rescued the Holocaust from semi-oblivion, but also promoted its deterritorialization. The Holocaust is recognised as a transnational past and memory transcending all (ethnic, national, spatial, even temporal) boundaries. The Shoah is no longer limited to specific places and territories, such as camps, ghettos or resettlement territories, where "the
[4] The chosen topics reflect (upon) the "putative essence" the Balkans, alleged balkaness - being part of the Balkanism understood as "dealing with the Balkans [...]. A Western style for dominating, restructuring, and having authority over the Balkans" (M. Todorova, op.cit., p. 7). On the other side, Balkanism also involves self-imagining, raising of self-awareness and auto construction of identity.
[5] L. Saxton, Haunted Images: Film, Ethics, Testimony and the Holocaust, London-New York 2008, p. 121.

[6] Ibidem, p. 9.

[7] N. Mandel, Rethinking 'after Auschwitz': against a rhetoric of the unspeakable in Holocaust writing,

"Boundary" 2001, vol. 28, no. 2, p. 219. 
horror is localized, abstracted, and isolated".[7] Innovative (hi)stories represented it as a historical trauma that took place at many different sites, as many specific and individual tragedies and tales of opposed and contrasted genres. The stories easily reached transnational audiences in various media formats, further stipulating the Holocaust as a "new cosmopolitan memory".[8]

In the Balkans, the "memory boom" that coincided with the erosion of socialism - the fall of the Berlin Wall and the remapping of the Eastern Europe - allowed the re-discovery and intense narrativisation of the Holocaust. Mate Zombory notes that the process helped the reintegration of Eastern Europe and the Balkans into "continental civilization" and that "the cultivation of the Holocaust memory became, by the second half of the 1990s, a 'soft membership criterion' to the EU". Nevertheless, he points that it also meant the reversal of the process of deterritorialization. "The EU began to embrace the global Holocaust discourse (Calligaro, 2015; Probst, 2013): it localized (Zombory, 2012) the deterritorialized memory of the Holocaust as a par excellence European historical experience, with universal significance".[9] Cinematic narratives thus argued that the Holocaust memory worked and existed on different levels - from national, regional/transnational, Balkan and European to cosmopolitan. Together with the Balkans' past and identity/ identities working within the same frameworks, the three are seen as in a permanent interplay of deconstruction and reconstruction.

The "honesty of remembrance" and the growing "awareness of historicity" [10] made Holocaust (hi)stories at the turn of the centuries[11] the subject matter of various films that served as an impetus for the re-configuration of the memory of WWII (about the participation and the role of the local population in pogroms and deportations) or for the restoration and construction of a larger memory (the Holocaust becomes a comparative point of reference for present-day historical events). For example, in the whole of the former Yugoslavia in the era 1945-1992 only four films were made about the Holocaust: Himmelkommando (Nebeski odred, 1956, B. Bošković, I. Nikolić); Five Minutes of Paradise (Pet minuta raja, 1959, Igor Pretnar)[12]; The Ninth Circle (Deveti krug, 1960, France Štiglic); The Fed One (Hranjenik, 1970, Vatroslav Mimica). Even more

[8] D. Levy, N. Sznaider, Memory unbound: The Holocaust and the formation of cosmopolitan memory, "European Journal of Social Theory" 2002, vol. 5 (1), pp. 87-106.

[9] M. Zombory, The birth of the memory to Communism: memorial museums in Europe, Nationalities paper, "The Journal of Nationalism and Ethnicity" 2017, vol. 45, p. 1029.

[10] A. Assman, Memory, individual and collective, in: The Oxford Handbook of Contextual Political Analysis, eds. R.E. Goodin, Ch. Tilly, Oxford 2006, pp. 210-224.
[11] 1950-1980 is the era of blissful oblivion, forgetting and intentional politically determined ignorance when the memories of the Balkan Jewry and Holocaust were almost invisible beyond local closed circles or were immersed into the global WW2 (hi)story. The reasons for the long time symptomatic silence are diverse, ranging from political, ideological personal to the (national) government proclaimed incompatibility of the Holocaust memory and media politics. [12] The film is borderline case as we presume that the prisoners in strapped unifroms - who come to the house the dismantle the bomb - are from the concentration camp. 
titles were almost totally silenced by film historians, while the real events were marginalised by the official historiography. Conversely, in barely two years, 2011-2012, three Holocaust films were made in ex-Yugoslav republics, now independent states: When the Day Breaks (Kad svane dan, 2012, Goran Paskaljević) and The Third Half (Treće poluvreme, 2012, Darko Mitrevski) were made in Serbia and Macedonia, respectively, both in the Balkans, while the film Lea and Darija (Lea i Darija, 2011, Branko Ivanda)[13] was made in Croatia, and thus in Central Europe. A similar production turn is found in other Balkan countries. Ivan Nitchev finished his loose trilogy (with After the End of the World, 1999; and The Journey to Jerusalem [Patuvane kam Yerusalim, 2003]) about the history of Bulgaria's Jewry with the 2014 film Bulgarian Rhapsody (Bulgaria-Israel). Holocaust memories in Romania are marked by Radu Gabrea`s Gruber's Journey (Călătoria lui Gruber, 2008) vastly different from the the emblematic yet maverick Holocaust comedy The Train of Life (Trenul vieţii, Radu Mihăileanu, France-Romania) from 1998. The recent Greek tale Ouzeri Tsitsanis (2015, Manousos Manousakis), an impossible, heart-breaking romance set in the time of the Holocaust, is an adaptation of the eponymous novel written by George Skarbadonis.

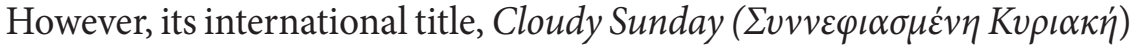
[14] refers to a Tsitsanis song that was a symbol of national sentiments and resistance during the German occupation.[15]

Five of these films[16] neatly fall into two categories. Three titles Bulgarian Rhapsody, Third Half, Cloudy Sunday - are old-fashioned melodramas following the traditional pattern established in the 1960 s by The Ninth Circle and The Stars (Sterne, 1959, Konrad Wolf, Bulgaria), about the failed rescue of a beloved (Jewish) girl. The other two tell the story of a search into a traumatic past (When the Day Breaks) or present (Gruber's Journey).

Bulgarian Rhapsody is a coming of age melodrama set in Sofia in 1943, a time of looming tragedy for the Jewish community, with a predictable end of a first, true love. "Nitchev compresses the wider racial politics of the era into a love triangle between three 17-year-olds. Moni (Kristian Makarov) is a shy young Jewish boy living in Sofia, Giorgio (Stefan Popov) is his more worldly Bulgarian friend, and Shelli (Angela

[13] As not being of Balkan provenance, the film Lea and Darija, although good case study, is beyond the scope of this research.

[14] Tsitanis song - originally named as Bloody Sunday - referred both to April $27^{\text {th }} 1941$ when German troops marched in, as well as to the incident witnessed by the composer of the Nazis killing a young Greek boy at one of the checkpoints.

[15] The list of contemporary Holocaust documentaries containing testimonies of Jewish survivors from Greece includes the titles like 39405 (2001, Kyriake Malama); Farewell My Island (2001, Isaac Dostis); Children in Hiding (Filia eis ta paidia, 2011, Vassilis
Loules) and Trezoros (Treasures: the Lost Jews of Kastoria, 2016, Larry Confino, Larry Russo). The fiction films - Brother Anna (O adelfos Anna, 1963, Grigoris Grigoriou); Amok (Dinos Dimopoulos, 1963); Treason (Prodosia, 1964, Kostas Manousakis) - are either melodramas, literary adaptations or are based on true events.

[16] In Albania there is recent documentary Besa: The Promise (The God's House, 2012, Rachel Goslins). In Turkey the emphasis is upon massacre of Armenians, never officially recognized as genocide anticipating Holocaust. 
Nedyalkova) is his flirtatious cousin who lives across the border in the Greek coastal town of Kavala." [17] In spite of all efforts and huge risks, the two friends fail to save Rachel (Shelli) from the train carrying Jews from the "new territories" [18] to a concentration camp.

In the Third Half, in vibrant multi-ethnic Skopje on the eve of the Bulgarian occupation, a rising football star, Kosta (Saško Kočev), falls in love with the beautiful Rebecca (Katarina Ivankovska), daughter of a local Sephardi banker (Rade Šerbedžija). Although storm clouds are gathering on the horizon, the team manager (Mitko Apostolovski) decides to hire a German Jew, Rudolph Spitz (Richard Sammel), as the team's new coach. The war begins and in an attempt to rescue both Rebecca and Rudolph from deportation, they have to play more than a simple football game; they have to play for life, for the rescue of their loved ones. The two narrative lines, love and sport, build into a national melodrama resembling the Serbian 2010 film Montevideo, God Bless You! (Montevideo, Bog te video!, Dragan Bjelogrlić). This filmic story of national identity - an identity continuously suppressed by belligerent neighbours - rooted in its mythical foundations, not surprisingly has resonated strongly in contemporary Macedonia.

Manoussos Manousakis' film, Cloudy Sunday, set in the city of Thessaloniki - then called the Second Jerusalem or the Jerusalem of the Balkans due to its large community of 45,000 Sephardi, which lived peacefully and integrated well with the Greeks - begins in 1942, in the midst of the escalating persecutions of Jews. It chronicles the destiny of doomed lovers - the man (Yorgos/Haris Fragoulis) is a Greek Christian, while the woman (Estrea/Christina Hilla Fameli) is of Jewish origin accompanied by the emotional overtones of Tsitanis's song.

When the Day breaks, based on the story of Filip David, offers in a rather dry historiographic manner the short history of Judenlager Semlin. Miša Brankov (Mustafa Nadarević), a retired professor of music, discovers on the site of a former concentration camp in Belgrade a metal box with the documents and an unfinished symphony. The tragic past about his parents killed in the camp while he survived, adopted by friends who took him in, unravels in front of his eyes. Miša decides to finish the composition, When the Day Breaks, of his father Isaac Weiss; and to make the concert on the site of the camp. The musical performance confirms the site as powerful lieu de mémoire. In the end, the Roma singer (Zafir Hadžimanov) is unable to utter a sound. He opens his mouth and moves his lips in vain. All we hear is a cosmic sound of silence, like the one in Thomas Mann`s Doctor Faustus (1947), that surrounds the Holocaust.

[17] S. Dalton, 'Bulgarian Rhapsody': Film Review, The Hollywood Reporter, 2014, December 23, <https:// www.hollywoodreporter.com/review/bulgarian-rhapsody-film-review-759977> [accessed on: 12.12.2017]. [18] Bulgarians resisted the mass deportation of their Jewish population - those holding Bulgarian citizen- ship - and managed to save some 48 ,ooo people. But they could not prevent the deportation of Jews from the "new territories". From more than 11,0oo people taken to Treblinka, only a few hundred survived. The destiny of Jews from Macedonia and Tracie features in the films Bulgarian Rhapsody and Third Half. 
Gruber's Journey, describes the experience of two journeys. The real journey is of the Italian writer Curzio Malaparte (Florin Piersic Jr.), who on his way to the Russian front as a war correspondent passes through Romania. He arrives in Jasi, where exhausted by an allergy, decides to make an appointment with the famous doctor Gruber (Marcel Lures). Searching for the doctor, Malaparte learns about pogroms and encounters the shocking images of Holocaust trains of death - tightly closed wagons left on tracks leading nowhere - and mass graves; he is appalled by the rigid administration and severe racial measures taken against Jews. Curzio is told that the doctor's name is on the list of dead. But the next day, to his utmost surprise, Gruber sends for the patient. He has just returned from a journey and is waiting for Malaparte in his consulting room. The good doctor was taken away and imprisoned with other Jews and thus his journey is both metaphorical (going almost into the death) and alleged one (as he was not travelling but sitting in the prison waiting for the execution). However, both journeys into the horrors of the Holocaust and war are ultimately resumed.

\author{
Melodrama \\ vs. historical fiction \\ and nostalgia \\ vs. trauma reloaded
}

Regardless of the dominant genre, all films skilfully laminate trauma and nostalgia, fiction and faction, past and present, in shaping Balkan Holocaust narratives after western models. TV series like Holocaust (1978), War and Remembrance (1988) or films like Schindler's List (1993, Steven Spielberg), as the epitome of the Americanisation of the Holocaust, brought trivialization, distortion and simplification of the trauma of the past. Under the decisive influence of Hollywood portrayals, Balkan cinema(s) began to engage different genre and representational patterns to rethink time, memory and history when fragmented by trauma; and a unique historical trauma became a simple "historical background for what could be just any other" (melo)drama.[19] Nested in historical fiction or melodrama, the Holocaust became something that it hardly was in reality.

The authors provide a straightforward happy end (Third Half) or comforting metaphysical triumph as the memories are preserved through various means of storytelling (Bulgarian Rhapsody) that sooth guilt consciences. In the film Cloudy Sunday, the parting of lovers gives Bettelheim's gloomy fairy tale a tone that makes viewers almost expect to hear that the characters lived happily ever after in cinematic memory. In one of the most poignant scenes, Estrea, stepping into the darkness of the wagon, and Yorgos, helplessly standing on the side, exchange a final, long look. The radiating love and unspoken promises metaphorically set them free and allow them to stay together for eternity. The eventual recognition of the trauma of the past (When the Day Breaks, Gruber's Journey), read as political remorse (for the past and present), assures a politically correct - and good if not happy - end and the triumph of poetic justice as being pertinent to new Holocaust narratives. At the

[19] A.H. Rosenfeld, Americanization of the Holo-

caust, "Commentary" 99, 1995, 19, no. 6, p. 36. 
same time, the typical Hollywood redemptive end brings an ephemeral and virtual solution to the real problems[20] of the Holocaust, caught between forgetting and remembrance.

Holocaust films re-configure the Balkan past and allow it to be seen either with nostalgia for difficult, yet glorious past days and stolen moments of happiness, or as a locus of trauma or revolt. Romance (melodrama) set against the background of a turbulent public history (historical fiction) successfully negotiates between an opposed nostalgia for and trauma of the past. A traditional melodrama narrative is saturated with manifold nostalgia nurtured by feelings of irrecoverable loss - of a way of life, times gone by, happy moments, people, friends, places, "paradise lost" - and the constant longing for a return to the past. The film experience provides a temporary solution to the interlaced pain of loss and passion of desire. The embellished imagining of a lost era - the heart of nostalgia - in Holocaust romances is expressed in carefully chosen quotes from films, music, posters, newspapers, books or neat reconstructions of the epoch that emotionally reverberate in the minds of the audience. Life in the happy and desperate Balkans is visibly imbued with a feeling that a world was coming to an end.[21] In their universe of amalgamated feelings, the teenagers from Sofia listen to American jazz, dream of pin-up girls, rehearse kisses a la Clark Gable or Humphrey Bogart. The poetic realism of everyday life in Thessaloniki is strengthened by the motive of escape from the brutality of everyday life (Cloudy Sunday). The youngsters dream of going away from Kavala to Costa del Maresme, which does not exist on any of the globes in Shelli's room; meanwhile, in Sofia they embark on a real journey to the promised land of Palestine (Bulgarian Rhapsody). Ethnic nostalgia is accommodated in the warm vintage images of the life of the Jewish community (Balkan folk, klezmer-style or rebetika melodies, weddings and family holidays, kafanas) that was - as we are all painfully aware of - already doomed to perish.

As mentioned earlier, the narrativisation of the Holocaust often slips from the (imagined) mists of nostalgia into the research of traumatic historical events (the pogrom in Jasi/Gruber's Journey; Judenlager Semlin/When the Day Breaks; deportation from the "new territories"/ Bulgarian Rhapsody, Third Half) or life stories (Third Half, Cloudy Sunday). The narratives, thus, border on biographical fiction (Cloudy Sunday), non-conventional docu-drama (Third Half, When the Day Breaks) or reconstructive fiction (Gruber's Journey).[22] However, the horrors and atrocities are merely suggested or implied, due to well-

[20] Ch. Gledhill (ed.), Home is Where the Heart is. Studies in Melodrama and the Woman's Film, London 1987.

[21] The world was heading into the time when it would find "all gods dead, all wars fought, all faiths to man shaken”. (S. Fitzgerald, This Side of Paradise, New York 1999, p. 32).
[22] In critical discourse, non-conventional docu drama (A. Insdorf, Indelible Shadows Film and the Holocaust, Cambridge 2003, p. 4) or non-fictional drama refers to the docu based narratives in which all the details are adapted for achieving desired dramatic and emotional experience. 
known real history, and not actually shown. The films do not "re-deploy metonymic images" ("metonymic traces of the Holocaust itself"), but rather create (and re-create original images of the preparations for or the aftermath of the trauma) "images which work at times to shield us from and at others to attest to the lack of visible evidence". [23] Due to fictionally recreated images of the ghettos, "trains of death", raids - but not of concentration camps, like in older films - the Hollywood-like narrativisation of Holocaust manages to overcome the problems and taboos defined by the ethics of representation. [24]

Heterogeneous encounters between of fiction and facts, equally dedicated to the construction of nostalgia, the rearticulation of the overall meaning and significance of the trauma, and the reinforcement of the sense of history, are realized in the editing of documentary and fiction footage. The Third Half cuts from TV reportage about the newly opened Macedonian Museum of the Holocaust and Hilary Clinton as its main patron, to fiction footage of Skopje in the 1940s. The neatly reconstructed city of the past clearly alludes to images of the picturesque Macedonian capital under Ottoman rule shot by the Manaki brothers. [25] The film ends with shots of Rebecca visiting the Museum and remembering family and friends who perished in the Holocaust. When the Day Breaks begins with the documentary film about the barely finished pavilions of the Fairground, which would become the barracks of the Judenlager Semlin, for the world Exhibition in 1937. In his nightmare Miša hears the names of the Jews deported to the camp in 1941. The suggestive and inferring documentary footage and facts give the story of the ordinary, half-anonymous people in the unusual and extraordinary circumstances of the Holocaust - as the formula of Holocaust films in the Balkans - emotional strength and historical persuasiveness.

Balkan filmmakers exploit the potential of memory/fantasy (melodrama) or fiction/history (historical fiction) to reveal hidden truths and repressed memories of the past in the present. The aura of the gracious saviour of the history and memory of the Holocaust told aloud and made visible - is bestowed upon cinema, which as an invisible third-person narrator, demiurgic storyteller and le grand imagiere,[26] becomes a memory maker and memory marker; the voice of the past and its two facets of history and memory. The two genres - acknowledging their own limitations and advantages, interlaced

[23] L. Saxton, Haunted Images: Film, Ethics, Testimony and the Holocaust, London-New York 2008, p. 14. [24] The Holocaust "is the emblem for the breakdown in divine and/or human history. The uniqueness of this break down delegitimises names and narratives as such and hence all aesthetic or apprehensive representation" (ibidem, p. 7). The ethics of representation is "gaining urgency at a time when even more diverse forms of Holocaust representation are emerging worldwide" (ibidem, p. 3). The traditional issues of the ethics of representation are radically changed by the Hollywood and Hollywoodized representation of the Holocaust. The new narratives dramatically redefine both issues: of what is told and of the ways of telling i.e. what is allowed to be told and whether the language and mode of storytelling exist?

[25] The short films are clearly cited in Dust (2001, Manchevski) and tacitly present in Angelopoulos' Ulysses Gaze (1995).

[26] A. Lafe, Logika filma, Beograd 1971. 
with history and memory and playing with facts and fiction, represent a hybrid testimony. Using this term to discuss various writings about trauma, Matthew Boswell explains:

Hybrid testimony is clearly not a documentary form concerned to establish bare facts, like a news-report, nor is it a mode of engagement with the past that is born entirely of imagination, like a work of fiction. It specifically demands that we navigate beyond the oppositional logic of silence and language, inside and outside, facts and fiction, truth and lies that has dominated critical response to Holocaust literature, refusing the absolute dominance of any of these terms.[27]

Hybrid testimony and hybrid genre pave the way for the re-thinking of the past and rewriting of memory and history.

The relation between two facets of the past, history and memory, is often seen as oppositional,[28] abusive (Lowenthal, 1998; Ricoeur, 2009; Hall, 2005; Assmann, 2006),[29] or denigrating for memory. Memory is rarely given the upper place as the one "we should turn (to) in order to reveal 'what really happened"'.[30]

The trauma of the Holocaust, specifically, marks the moment of a break up between history and memory that is to be reunited in texts. However, reloaded through images with hidden traumatic potential and not real traumatic incidents, such as death, concentration camps etc., trauma also provides a privileged vantage point for reconsideration of the past in an attempt "to establish the historical record of the events [...] and the desire to facilitate collective remembrance and mourning". [31] In other words, docu images work for the convergence of history generated by historical records and memory shaped through recuperated collective remembrance and mourning. The double emotionalism of nostalgia and trauma further erodes the dualism of history and memory.

Balkan cinema assumes "the narrative potential of handing down history and applied itself to representing genocide and crimes against humanity",[32] breaking the silence that surrounded the Holocaust hidden behind the overall story of WWII. The memory tales and (hi)stories

[27] M. Boswell, Beyond Autobigraphy: Hybrid testimony and the Art of Witness, in: The Future of Testimony: Interdisciplinary Perspectives on Witnessing, eds. A. Rowland, J. Kilby, New York 2014, p. 153. [28] M. Halbwachs, The Collective Memory, New York 1980; P. Nora, Between Memory and History: Les lieux de mémoire, Representations 1989, Special Issue: Memory and Counter-Memory, <http://www.jstor. org/stable/2928520?seq=1\#page_scan_tab_contents $>$ [accessed on: 12.12.2017].

[29] D. Lowenthal, The Heritage Crusade and the Spoils of History, Cambridge 1998; P. Ricoeur, Memory, History, Forgetting, Chicago 2009; S. Hall, Whose heritage? Un-settling 'the heritage', re-imagining the

\section{History and memory reconciled}

post-nation, in: The Politics of Heritage: the Legacies of 'Race', eds. J. Littler, R. Naidoo, London 2005; A. Assman, op.cit.

[30] K. Hodgkin, S. Radstone, Introduction: Contested pasts, in: Contested Pasts: The Politics of Memory, eds.

K. Hodgkin, S. Radstone, London 2003, p. 12.

[31] Kansteiner cit. in Ch. Lorenz, Unstuck in time. or: the sudden presence of the past, in: Performing the Past: Memory, History, and Identity in Modern Europe, eds. K. Tilmans, F. van Vree, J. Winter, Amsterdam 2010, p. 69.

[32] A. Baron, The Shoah on the Screen: Representing Crimes against Humanity, Strasbourg 2006, vol. 1, p. 8. 
created argue that the Holocaust is "a never-ending process that goes through various film genres and media forms"; that its narratives are "not a closed set of facts but an archive project of memory in constant development".[33] The new Balkan Holocaust cinematic fiction, thus, is a powerful keeper of the past and of memories. Its adjusted narratives become points of conversion of history and memory presented in cinematic fiction. Ultimately, "the 'history' of the Holocaust that is made available to most people most of the time, is largely a product of popular culture and does not always derive from or necessarily conform to the history of the Jews under Nazism that professional historians strive to establish". [34] On one side, the fiction interventions of melodrama in the facts of history create the narrative of the shared Balkan memory and popular history; on the other side, they immerse the stories in (cultural) memory. In and from the domain of memory, the Holocaust speaks for its own impossibility to be historicized, "as it is always contingent in our cultural and mental presence, is inscribed and accommodated as part of our cultural consciousness".[35]

Thus it has the potential to powerfully resonate in present-day political crises. The courage of Bulgarians (Bulgarian Rhapsody), Greeks (Cloudy Sunday) or Macedonians (Third Half) to stand up in defence of the local Jewish community testifies to their determination to stand up for themselves, for the preservation of own national identity and dignity and for going against the hardships of contemporary times. The Holocaust is used as a context which ascribes value to the heroism of the nation and explains the nostalgia that people feel about the past because it represents better times. It was a time of unity and humanism unlike the present day, when Balkan societies are divided by serious socio-political crises (Greece) or in constant turbulent transition ( $\mathrm{Ru}$ mania, Bulgaria, Serbia, Macedonia). Furthermore, examples from memory are read as atonement for and a raising of self-awareness about shameful episodes in the present: the relation to and treatment of the Roma population (When the Day Breaks), the crises of immigrants flooding in from the Middle East (Bulgarian Rhapsody, Third Half), or the atrocities in recent wars (Gruber's Journey). The Holocaust palimpsest of bounded identities of the war-time period and of Jewish traumatic memory are seen as models for the solution of problems in radicalized social, national and economic circumstances. [36]

[33] N. Daković, Studije filma: ogledi o filmskim tekstovima sećanja, Beograd 2014, p. 165.

[34] A.H. Rosenfeld, The End of the Holocaust, Bloomberg 2011, p. 15.

[35] S. Frank, The visual sites of memory: the Holocaust from the screen to cultural memory, in: Zbornik radova sa naučnog skupa Menadžment dramskih umetnosti i medija - izazovi XXI veka, Beograd 2014, p. 153 .

[36] After all (cultural) memory, regardless of its emotional tone or structure, is the medium of identity building or of creation other elements that give us stability and continuity. It preserves the store of knowledge - the one involving living processes in the past, changes of society and culture and of their forms - from which a group derives as awareness of its unity and peculiarity. (I. Assmann, J. Czaplika, Collective Memory and Cultural Identity, New German Critique "Cultural History/Cultural Studies" 1995, no. 65 , pp. 125-133). 
The recognised group of Holocaust films from the Balkan lands shares a necessary consistency to the notions of the Balkan shared past, memories and history that further serve as the basis of a transnational and supranational identity in the region. Stories of the past are modelled after a common narrative and genre pattern - melodrama and historical fiction - that evokes the pertinent double emotionalism of nostalgia and trauma. These similarities allow the construction of a shared, regional, Balkan identity. The nuanced differences between local and national Holocaust events allow for the articulation of national identity and memory. Mediatized memories eventually influence non-mediatized ones. Scenes from films like When the Day Breaks or Gruber's Journey respectively replace historical accounts or oral testimonies about Judenlager Semlin or the events in Jasi.

In visualising and narrating the Holocaust - even in metonymic images and without recourse to documentary footage - the films invites unwelcome comparisons between the past and the present. Re-dressing the trauma of the past, the films present thw possible trauma of a future reconfirming the "Holocaust dictum 'never forget". Cinematic hybrid testimonies about the past of the Balkans assert the (possible) identity of the Balkan cinema(s) in the present.

The Balkan identity and past (history and memory) reflect the Janus faced structure of Holocaust memory and films and vice versa. They are both national (of distinctive Balkan countries) and transnational (sustaining the notion of the region as the entity); local (Balkan) and global or cosmopolitan (accommodated within European and world framework); they relate past, present and future, facts and fiction. These hybrid narratives and testimonies - in terms of genre, fiction and documentary material - argue for a polarized notion of the Balkans, its past, and its identity and cinema in singular and plural. The new cinematic representational paradigm gives consistency to Balkan (hi) stories of the past and coherence to the identity in the present.

Assman A., Memory, individual and collective, in: The Oxford Handbook of Contextual Political Analysis, eds. R.E. Goodin, Ch. Tilly Ch, Oxford 2006

Assmann I., Religion and Cultural Memory, Stanford 2006

Assmann I., Czaplika J., Collective memory and cultural identity, new German critique, "Cultural History/Cultural Studies" 1995, no. 65

Barenboim D., Said E., Parallels and Paradoxes: Explorations in Music and Society. New York 2004

Baron A., The Shoah on the Screen: Representing Crimes Against Humanity, Strasbourg 2006, vol. 1

Boswell M., Beyond autobiography: hybrid testimony and the art of witness, in: The Future of Testimony: Interdisciplinary Perspectives on Witnessing, eds. A. Rowland, J. Kilby, New York 2004

Daković N., Balkan kao (filmski) žanr: Slika, tekst, nacija, Beograd 2008 
Daković N., Images from the fringes: Balkanism in world cinema, "Spaces of Identity" 2001, vol. 1, no. 1, <http://www.arts.ualberta.ca/CCAuCES/spacesofidentity/ start.html> [accessed: 12.12.2017]

Daković N., Studije filma: ogledi o filmskim tekstovima sećanja. Beograd 2014

Dalton S., 'Bulgarian rhapsody': Film review, “The Hollywood Reporter” 2014, December 23, <https://www.hollywoodreporter.com/review/bulgarian-rhapsody-film-review-759977> [accessed: 12.12.2017]

Fitzgerald S., This Side of Paradise, New York 1999

Frank S., The visual sites of memory: the Holocaust from the screen to cultural memory, in: Zbornik radova sa naučnog skupa Menadžment dramskih umetnosti i medija - izazovi XXI veka, Beograd 2014

Gledhill C. (ed.), Home is Where the Heart is. Studies in Melodrama and the Woman's Film, London 1987

Halbwachs M., The Collective Memory, New York 1980

Hall S., Whose heritage? Un-settling 'the heritage', re-imagining the post-nation, in: The Politics of Heritage: the Legacies of 'Race', eds. J. Littler, R. Naidoo, London 2005

Hodgkin K., S. Radstone, Introduction: contested pasts, in: Contested Pasts: The Politics of Memory, eds. K. Hodgkin, S. Radstone, London 2003

Insdorf A., Indelible Shadows Film and the Holocaust, Cambridge 2003

Iordanova D., Cinema of Flames: Balkan Film, Culture, and the Media, London 2001

Lafe A., Logika filma, Beograd 1971

Levy D., Sznaider N., Memory unbound: The Holocaust and the formation of cosmopolitan memory, "European Journal of Social Theory" 2002, vol. 5 (1)

Lorenz C., Unstuck in time. or: the sudden presence of the past, in: Performing the Past: Memory, History, and Identity in Modern Europe, eds. K. Tilmans, F. van Vree, J. Winter, Amsterdam 2010

Lowenthal D., The Heritage Crusade and the Spoils of History, Cambridge 1998

Mandel N., Rethinking 'After Auschwitz': Against a Rhetoric of the Unspeakable in Holocaust Writing, "Boundary" 2001, vol. 28, no. 2

Margalit A., The Ethics of Memory, Harvard 2002

Nora P., Between Memory and History: Les lieux de mémoire, "Representations" 1989, Special Issue: Memory and Counter-memory, no. 26, <http://www.jstor.org/ stable/2928520?seq=1\#page_scan_tab_contents $>$ [accessed on: 12.12.2017]

Ricoeur P., Memory, History, Forgetting. Chicago 2009

Rosenfeld A.H., Americanization of the Holocaust, "Commentary" 1995, 99, no. 6

Rosenfeld A.H., The End of the Holocaust, Bloomington 2011

Saxton L., Haunted Images: Film, Ethics, Testimony and the Holocaust. London-New York 2008

Schmahl S. et al., The Council of Europe: Its Law and Policies, London 2017

Todorova M., Imagining the Balkans, New York 1997

Wolff L., Inventing Eastern Europe: The Map of Civilization on the Mind of the Enlightenment, Stanford 1994

Zombory M., The Birth of the memory to communism: Memorial museums in Europe, Nationalities paper: "The Journal of Nationalism and Ethnicity" 2017, vol. 45, no 6 .

F I L M O G R A P H Y

39405 (2001, Kyriake Malama)

After the End of the World (1999, Ivan Nitchev)

Amok (1963, Dinos Dimopoulos) 
Ulysses Gaze (1995, Theodoros Angelopoulos)

Brother Anna (O adelfos Anna, 1963, Grigoris Grigoriou)

Bulgarian Rhapsody (2014, Ivan Nitchev)

Children in Hiding (Filia eis ta paidia, 2011, Vassilis Loules)

Cloudy Sunday (Ouzeri Tsitsanis, 2015, Manousos Manousakis)

Dust (2001, Milcho Manchevski)

Farewell, My Island (2001, Isaac Dostis)

Five Minutes of Paradise (Pet minuta raja, 1959, Igor Pretnar)

Gruber's Journey (Calatoria lui Gruber, 2008, Radu Gabrea)

Himmelkommando (Nebeski odred, 1956, B. Boskovic, I. Nikolic)

Holocaust (1978, TV Mini-Series),

Lea and Darija (Lea i Darija, 2011, Branko Ivanda)

Montevideo, God Bless You! (Montevideo, Bog te video! 2010, Dragan Bjelogrlić)

Schindler's List (1993, Steven Spielberg)

The Fed One (Hranjenik, 1970, Vatroslav Mimica)

The Journey to Jerusalem (Patuvane kam Yerusalim, 2003, Ivan Nitchev)

The Ninth Circle (Deveti krug, 1960, France Štiglic);

The Stars (Sterne, 1959, Konrad Wolf)

The Third Half (Treće poluvreme, 2012, Darko Mitrevski)

The Train of Life (Trenul vieţii, 1998, Radu Mihăileanu, France-Rumania)

Treason (Prodosia, 1964, Kostas Manousakis)

Trezoros (Treasures: the Lost Jews of Kastoria, 2016, Larry Confino, Larry Russo)

War and Remembrance (1988, TV Mini-Series)

When the Day Breaks (Kad svane dan, 2012, Goran Paskaljević) 